\title{
Mechanized fertilization: individual application of nitrogen, phosphorus and potassium in sugarcane ${ }^{1}$
}

\author{
Adubação mecanizada: aplicação individualizada de nitrogênio, fósforo e potássio em \\ cana-de-açúcar
}

\author{
Franciele Morlin Carneiro ${ }^{2 *}$, Carlos Eduardo Angeli Furlani ${ }^{3}$, Antonio Tassio Santana Ormond ${ }^{3}$, Elizabeth \\ Haruna Kazama ${ }^{3}$ and Rouverson Pereira da Silva ${ }^{3}$
}

\begin{abstract}
With the expansion of areas of sugarcane cultivation, mechanised fertilisation is essential for providing improved operational performance, optimising the supply of nutrients and increasing productivity. However, this type of fertilisation may present deficiencies in the area of distribution, such as fluidity, separation, and particle size, among others. A new concept in fertilisation is therefore being developed, capable of carrying out the individual application of nitrogen, phosphorus and potassium, distributing these in various doses, with greater efficiency of application, employing precision farming and variable rates. The aim of this study was to evaluate the quality of the individual mechanised fertilisation of NPK in ratoon cane by means of Statistical Quality Control - SQC. The experiment was carried out in the city of Matão, in the State of São Paulo, with the experimental area making up part of the Cascavel Farm. The experimental design was based on the basic premise of spatial SQC, monitoring the individual mechanised fertilisation of NPK at 30 sampling points. For this treatment, the lots were composed of six rows of sugarcane, spaced $1.5 \mathrm{~m}$ apart, with an effective area of $1,571 \mathrm{~m}^{2}$. There was a sampling point every $30 \mathrm{~m}$, where fertiliser was collected for 5 seconds. The helical metering system especially affected operational quality, as this was inefficient in its distribution. It was concluded that, due to adjustment of the helical metering system, individual application resulted in doses above those recommended for all fertilisers. Nitrogen (protected urea) showed the greatest variability in distribution, whereas phosphorus (MAP) displayed the highest operating quality due to the lower recommended volume.
\end{abstract}

Key words: Statistical process control. Mechanised agriculture. Saccharum spp.

RESUMO - Com a expansão de áreas de cultivo de cana-de-açúcar, a adubação mecanizada mostra-se fundamental por proporcionar maior desempenho operacional, otimização do fornecimento de nutrientes, aumento da produtividade. Porém, esta adubação pode apresentar algumas deficiências na distribuição, tais como, fluidez, segregação, granulometria, entre outros. Assim, está sendo desenvolvido um novo conceito de adubação, capaz de realizar aplicação individualizada de nitrogênio, fósforo e potássio, distribuindo-os com diferentes dosagens; maior eficiência de aplicação; utilização da agricultura de precisão e taxa variável. Objetivou-se com este trabalho avaliar a qualidade da adubação mecanizada individualizada de NPK em cana-soca por meio do Controle Estatístico de Qualidade - CEQ. O experimento foi desenvolvido no município de Matão, São Paulo. A área experimental pertence à Fazenda Cascavel. O delineamento experimental foi baseado nas premissas básicas do CEQ ao longo do espaço, monitorando a adubação mecanizada individualizada de NPK em 30 pontos amostrais. As parcelas desse tratamento foram compostas por seis linhas de cana-de-açúcar, espaçamento entrelinhas de 1,5 m, área útil $1.571 \mathrm{~m}^{2} \mathrm{e}$ a cada $30 \mathrm{~m}$ coletou-se por 5 segundos o fertilizante nos pontos amostrais. O mecanismo dosador helicoidal foi uma das causas especiais que afetou a qualidade operacional, pois não foi eficiente na distribuição. Concluiu-se que a qualidade da adubação individualizada de fertilizante aplicou a dosagem acima da recomendada para todos os fertilizantes, devido à regulagem e o mecanismo dosador helicoidal. O nitrogênio (ureia protegida) apresentou maior variabilidade de distribuição enquanto o fósforo (MAP) apresentou a melhor qualidade operacional devido a menor quantidade recomendada.

Palavras-chaves: Controle estatístico de processo. Mecanização agrícola. Saccharum spp.

DOI: $10.5935 / 1806-6690.20170032$

*Autor para correspondência

Recebido para publicação em 27/09/2015; aprovado em 08/08/2016

${ }^{1}$ Parte da Dissertação de Mestrado do primeiro autor apresentada ao Programa de Pós-Graduação em Agronomia (Produção Vegetal) da UNESP Campus de Jaboticabal, pesquisa financiada com recursos da CAPES

${ }^{2}$ Departamento de Engenharia Rural/FCAV/UNESP, Via de Acesso Prof. Paulo Donato Castellane s/n Jaboticabal-SP, Brasil, 14.884-900, franmorlin1@gmail.com

${ }^{3}$ Departamento de Engenharia Rural/FCAV/UNESP, Jaboticabal-SP, Brasil, furlani@fcav.unesp.br, rouverson@gmail.com, tassiormond@gmail.com, bethkazama@hotmail.com 


\section{INTRODUCTION}

Brazil is the biggest sugarcane producer in the world, representing approximately two thirds of the global production. According to the gross value generated and the production area, the sugarcane crop occupies the third place in economical significance on the Brazilian agricultural market, only behind soy and corn (VOLTOLINI et al., 2012).

For the 2014/2015 harvest, the sugarcane production in Brazil was accounted in an amount of approximately 634.8 million tones, with $9,004.5$ ha of cultivated area. Compared to the previous harvest, a production loss of 3.75 was noticed, being associated to the productivity reduction of $5.7 \%$. The production loss was not bigger due to the extension of the cultivated Brazilian area in 2.2\% (CONAB, 2015).

For Brazil to remain the biggest producer, new technologies that enable the raise of productivity must be adopted; according to Motomiya et al. (2011), precision farming is a technique that contributes to the efficient use of fertilizers, considering the diversity of the soil and the plantations, aiming towards a more precise distribution, applying them properly, economically and with more concern for the environment.

The use of fertilizers is efficient when it considers how old the plantation is, the crop phase (cane-plant or ratoon cane), rainy period, its' physiological condition, proper season for fertilization, type of soil and the analysis result (VITTI et al., 2005).

Due to the need for sustainable handling of agricultural fertilizers, especially in the reduction and/ or in the costs of the individualized distribution of the nutrients (NPK), studies are necessary for the variability of the mechanic fertilization process of ratoon cane.

For the monitoring of the mechanic fertilization operational quality, the statistical quality control (SQC) was used, that is, a statistical technique that analyses the quality of a given mechanic operation through control charts, histograms, Pareto chart, Ishikawa diagram, among others. Therefore, it has as a goal to check the quality in the process and the potential failures, aiming to minimize them (MILAN; FERNANDES, 2002; SILVA et al., 2013).

Works with fertilization that individually distributes protected urea $(\mathrm{N})$, MAP $(\mathrm{P})$ and potassium chloride $(\mathrm{K})$ in sugarcanes could not be found in the literature. This experiment may serve as a foundation for future works, through operational capacity and adopting variable rates of the fertilizers, and it may be a new factor to be analyzed, with the possibility of purchasing individually each nutrient.
With this work, the aim was to assess the quality of the individual mechanized fertilization of nitrogen, phosphorus and potassium in ratoon cane through the SQC, comparing the recommended dosage to the applied dosage and the fertilizer machine aspect.

\section{MATERIAL AND METHODS}

The experiment was developed in the municipality of Matão, São Paulo. The experimental area belongs to Fazenda Cascavel, in the geographical coordinates $21^{\circ} 35^{\prime} 55,03$ ' $\mathrm{S}$ and $48^{\circ} 25^{\prime} 21,12^{\prime \prime} \mathrm{W}$ and $589 \mathrm{~m}$ of altitude, with a history of seven years of cultivation with sugarcane.

The weather of the municipality, according to the Köppen classification, is Aw, with tropical climate and dry winter. The temperature varies between $16{ }^{\circ} \mathrm{C}$ and $29^{\circ} \mathrm{C}$ and the rainy season is concentrated from October to March, with a total annual rainfall of approximately $1,400 \mathrm{~mm}$.

The soil of the experimental area is dystrophic argisolic YELLOW LATOSOL, with average-sandy/ average texture.

The chemical soil analysis was performed after the harvest of the sugarcane. The amount of fertilizers applied was based on the result of the soil analysis, with: $160 \mathrm{~kg} \mathrm{ha}^{-1}$ of potassium chloride - $\mathrm{KCl}(60 \%$ of $\left.\mathrm{K}_{2} \mathrm{O}\right), 290 \mathrm{~kg} \mathrm{ha}^{-1}$ of protected urea reviewed per polymer (45\% of $\mathrm{N}$ ) and $100 \mathrm{~kg} \mathrm{ha}^{-1}$ of MAP - monoammonium phosphate ( $45 \%$ of $\mathrm{P}_{2} \mathrm{O}_{5}$ and $11 \%$ of $\mathrm{N}$ ).

The experimental area had an average length of $297.80 \mathrm{~m}$, the floor area had $1,571 \mathrm{~m}^{2}$ and at every $30 \mathrm{~m}$ the fertilizer was collected for five seconds in the sampling points. The cultivar planted in this area was RB 867515, in the ratoon cane stage ( sixth cut). The mechanized harvest of the sugarcane has occurred between August 01 and 04, 2014.

The experimental delineation was based on the fundamental premises of the Statistical Quality Control (MONTGOMERY, 2009) throughout the space monitoring the individual mechanized fertilization of protected urea (nitrogen), MAP (phosphorus) and potassium chloride (potassium) in 30 sampling points. The installments of the treatments were composed by six sugarcane rows, equivalent to three subsequent strides of a tractor with floor area of 1,571.1346 $\mathrm{m}^{2}$ and perimeter of $604.8986 \mathrm{~m}$. The fertilizer machine (Figure 1) distributes the fertilizer on both sides of a row and on one side of each adjacent row. The spacing between rows of the culture was $1.5 \mathrm{~m}$.

In the floor area, the sampling points were placed $50 \mathrm{~m}$ away compared to the beginning of 
Figure 1 - Components of the fertilizer machine: Fertilizer machine reservoir (1), Cutting disk (2), Pipes (3), Stem (4), Cutout disks (5); Spray bar (6)

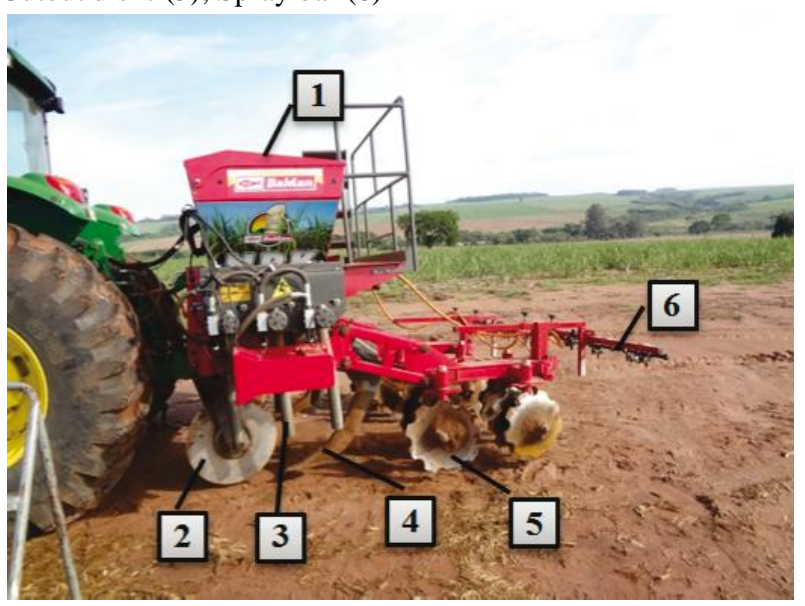

the experimental area (offset) with interval of $30 \mathrm{~m}$ between each other (Figure 2).

To perform the fertilization, a John Deere tractor, model $6145 \mathrm{~J}$ was used, with engine power in the nominal speed of $107 \mathrm{~kW}(145 \mathrm{cv}), 4$ x 2 TDA, PowerQuad 16 x 6 transmission, gauge size of $1.80 \mathrm{~m}$ and classification of the front tires 18,4-26 and of the rear tires 24,5-32.

The fertilizer machine used in this experiment belongs to the company BIA - Baldan that it is in development for the sugarcane line, model CAMB-AP. The fertilizer machine is composed by three individual reservoirs with capacity of $1000 \mathrm{~kg}$ for each fertilizer; 12 pipes conduct the NPK, facilitating their application over the soil, that is, three pipes in each side of the machine and six pipes at its center; a stem allows the mobilization of the soil, the tip with 3" of width and distance of 1500 $\mathrm{mm}$ between stems; and cutout disks for the incorporation of the fertilizers applied on the soil, with a diameter of 18 " and 11" of spacing between disks and distance of 34 " between the pairs of these disks; cutting disks - cut of the haystack of the crop to avoid the clogging of the machinery, presents a diameter of 22" and a distance of $750 \mathrm{~mm}$ between disks; and the spray bar for the application of herbicide.

The variable analyzed was the distributed amount of NPK fertilizers applied independently one from the other. In the whole area, the tractor used the 2nd B gear, with motor rotation of $1800 \mathrm{rpm}$ and average speed of $5.7 \mathrm{~km} \mathrm{~h}^{-1}$.

The fertilizer was collected in 30 sampling points with the help from a tool designed specifically for this aim - a metal frame with support for three measuring cups with capacity of $1000 \mathrm{~kg}$. The bar of this tool has a length of $1 \mathrm{~m}$, the basket of the collector glass has a length of 28", each measuring cup has a diameter of 11 " and spacing between them of 13 ". The fertilizers were collected in each side of the fertilizer machine, called left side and right side.

The fertilizers were collected only at the sides of the fertilizer machine (left side and right side), where there are three pipes for each nutrient (protected urea - N, MAP - P and potassium chloride - K). During the operation, when the tractor arrived at the respective sampling point, the operator activated the lifting of the three-point hitch hydraulic system along with the fertilizer machine, and then the sampler is placed in the guide pipes in both sides (left/right). Afterwards, the operator activated the button to release the fertilizer for about five seconds, the collection period.

The fertilizer retained in the three recipients was placed in plastic bags identified with the following information: side of the fertilizer machine, nutrient collected and sampling point.

Figure 2 - Diagrammatic drawing of the sampling points in the experimental area
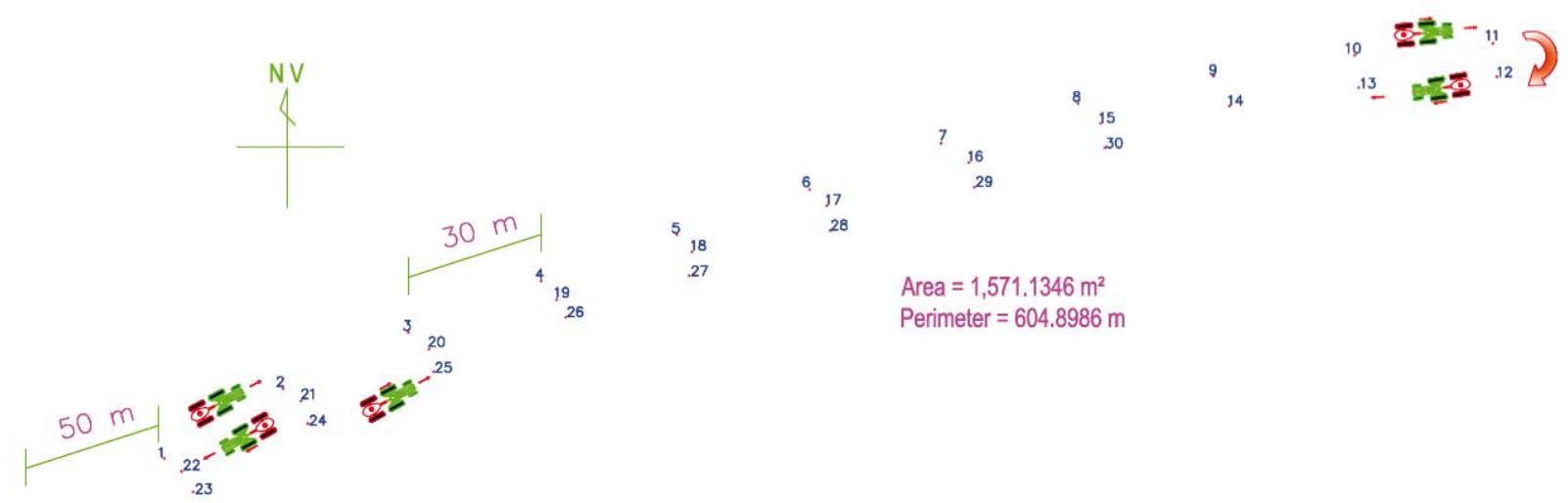
The statistical analysis used in this work was by means of the statistical process control (SPC), applying the descriptive analysis and control charts for the monitoring of the variability of the variables analyzed, since the larger the variability, the smaller is the quality. Besides, it allows the observing of the values outside the control limits (special causes) that affect quality, enabling the identification of the potential special causes for the correction of the failures that occurred in the process, with the aim to raise the quality with less amount of errors (SILVA et al., 2013).

In this work, the following descriptive analysis were made: standard deviation, total range and coefficient of variation (dispersion measures); mean and median (localization measures); coefficient of skewness and kurtosis (measures of the form of distribution). It was also performed the normality test through Ryan-Joiner, checking the data distribution.

To qualify the operation of mechanized fertilization in sugarcane, control charts were used through the Statistical Process Control (SPC), assessing the operational quality of the distribution of the fertilizers. The quality of this operation was based on the variability of the data collected, since the variability is inversely proportional to quality.

The control charts are composed by the mean and median amplitude situated in the central lines, respectively, of the moving range and individual values charts. In addition, these charts also have a lower and upper control limits (LCL and UCL) resulting from the mean and standard deviation of the values analyzed per parameter, with $\mathrm{LCL}=$ mean $=3$ times the standard deviation and $\mathrm{UCL}=$ mean +3 times the standard deviation (TOLEDO et al., 2008).

The process charts were generated through the IMR (Individual - Moving Range), providing draw-ups of processes charts with two graphics: the first corresponds only to the individual values; in this case, the fertilizer that was collected in each sampling point. The second refers to the Moving Range, that is, the difference between the current value and the previous value, based on the individual values. The Individual Moving Range was used to draw-up charts with the sides of each nutrient that were grouped in the same chart.
The specific control limits (SCL) were determined by meetings based on agronomic concepts, aiming to meet the goals presented by the rural producer or companies. However, the upper control limits (UCL) and the lower control limits (LCL) are obtained through statistical calculations (MILAN; FERNANDES, 2002).

The specific limits used were at $20 \%$, aiming to provide a strict test and operational quality of $80 \%$. Besides, these limits were stipulated by the academic technical team in partnership with the producer according to the result of the soil analysis, and they are the goal of each fertilizer (Table 1).

\section{RESULTS AND DISCUSSION}

Below is the analysis of the efficiency of distribution of each fertilizer (protected urea, MAP and potassium chloride) through control charts and descriptive analysis.

\section{Individual mechanized fertilization with protected urea}

In the individual mechanized fertilization with protected urea, the right side $(\mathrm{R})$ achieved the highest mean, with $448 \mathrm{~kg} \mathrm{ha}^{-1}$ compared to the left side (L) with $389 \mathrm{~kg} \mathrm{ha}^{-1}$. The mean values were relatively close to the median values. The standard deviation was bigger in the $\mathrm{R}$ side with 104, therefore, the values were further away one from the other. The coefficient of variation $(\mathrm{CV})$ of the right side was $23.14 \%$ e of the left side was $20.48 \%$ (Table 2).

According to Reis (2009), the dispersion measures, such as standard deviation, total amplitude and coefficient of variation, show the distribution of values around the mean, having it as a reference. These measures enable the analysis of the variability of the data studied.

The skewness coefficient for the right side $(\mathrm{R})$ presented negative skew distribution. However, on the left side (L), it has presented positive skew distribution. The coefficient of kurtosis of the $\mathrm{R}$ and $\mathrm{L}$ sides, in comparison, showed leptokurtic distribution with more concentrated data (Table 2).

In some statistical programs, such as Minitab (MINITAB, 2007), there is a standardization of the coefficient

Table 1 - Specific control limits used to calculate the dosages of the fertilizers collected in the sugarcane crop

\begin{tabular}{lccc}
\hline Quality indicator in the mechanized fertilization & Lower Specific Limit (LSL) & GOAL & Upper Specific Limit (USL) \\
\hline Protected Urea $\left(\mathrm{kg} \mathrm{ha}^{-1}\right)$ & 232 & 290 & 348 \\
MAP $\left(\mathrm{kg} \mathrm{ha}^{-1}\right)$ & 80 & 100 & 120 \\
Potassium Chloride $\left(\mathrm{kg} \mathrm{ha}^{-1}\right)$ & 128 & 160 & 192 \\
\hline
\end{tabular}


Table 2 - Descriptive analysis of the individual mechanized fertilization with protected urea

\begin{tabular}{cccccccccc}
\hline Side & Mean* & M & $\sigma$ & CV & Amp & Cs & Ck & RJ & P \\
\hline R & $448 \mathrm{a}$ & 450.20 & 103.60 & 23.14 & 636.80 & -0.68 & 5.68 & 0.913 & $<0.010 \mathrm{~A}$ \\
L & $389 \mathrm{~b}$ & 376.50 & 79.60 & 20.48 & 461.60 & 0.24 & 3.81 & 0.923 & $<0.010 \mathrm{~A}$ \\
\hline
\end{tabular}

R: right side; E: left side; M: median; $\sigma$ : standard deviation; CV: coefficient of variation; Amp: Amplitude; Cs: coefficient of skewness; Ck: coefficient of kurtosis; RJ: Ryan-Joiner normality test; P: probability value through the Ryan-Joiner test; A: asymmetrical distribution with $\mathrm{p}<0.05$; * Means followed by the same letter do not have statistical difference, at the $10 \%$ of significance level per the Tukey test

of kurtosis $(\mathrm{Ck})$, which can be determined as: mesokurtic distribution $(\mathrm{Ck}=0)$; platykurtic distribution $(\mathrm{Ck}<0)$; and leptokurtic distribution $(\mathrm{Ck}>0)$. In addition, the $\mathrm{Ck}$ classified the dispersion of the data regarding the parameter, with the mesokurtic distribution (TAVARES et al., 2015).

Noronha et al. (2011), reported the measures of skewness through the descriptive analysis of the experiment, where the Cs presented positive and negative skew distributions, in comparison to the $\mathrm{Ck}$ with values next to 0 . Therefore, these coefficients served as parameters to indicate the data distribution, making it possible to check the normality (or lack thereof) of the variables.
The values presented in Table 3 showed skewness in both sides, at the 5\% level, through the Ryan-Joiner normality test.

Noronha et al. (2011) checked in a work that analyzed the mechanized harvest that hypothesis tests, such as Shapiro-Wilk, Anderson-Darling and Kolmogorov-Smirnov, strictly analyze the normality of the variables, and most of the times, these tests reject the hypothesis of normality - therefore, they must be used with caution and wisdom.

For the control chart of the individual mechanized fertilization with protected urea, it was checked that the

Figure 3 - Control chart for individual mechanized fertilization with protected urea

(A)

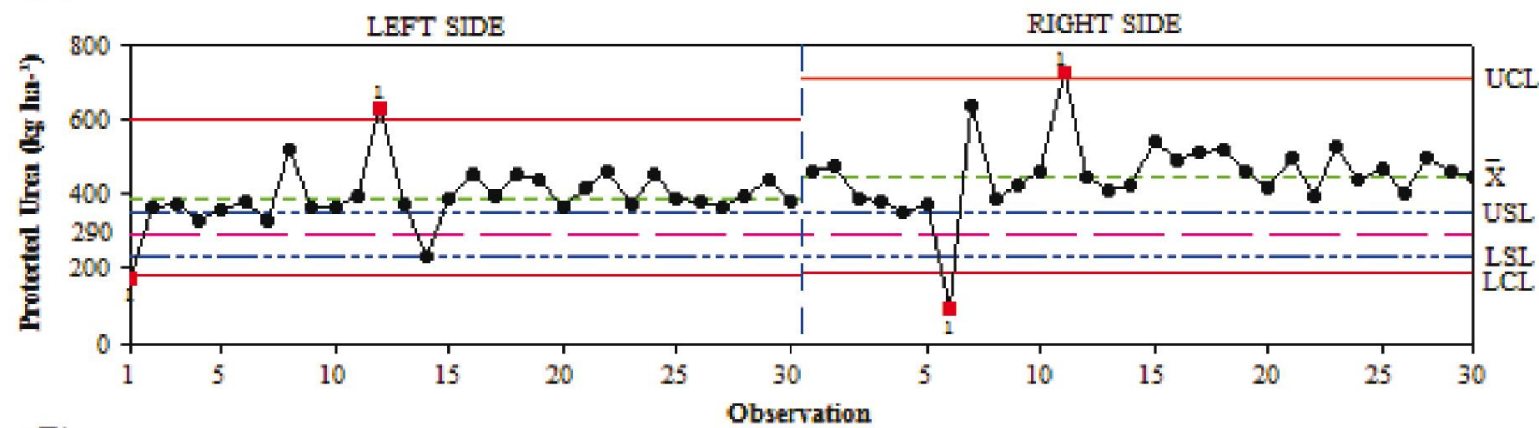

(B)

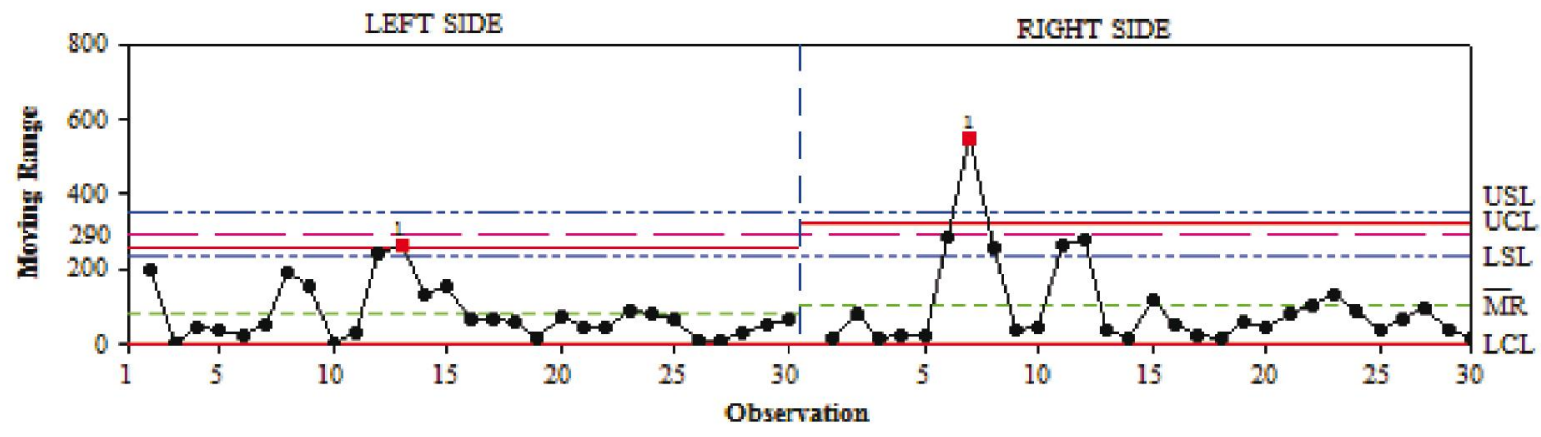

UCL: Upper Control Limit; X: Mean of the individual values; USL: Upper Specific Limit; LSL: Lower Specific Limit; LCL: Lower Control Limit; MR: Mean of the individual moving range 
individual values in the left side and right side presented two points positioned out of the control limits (Figure $3 \mathrm{~A}$ ). In the control charts with the moving range, one point was above the upper control limit (UCL) on both sides (Figure 3B).

For the specific limit of individual values, in the left side, three points were within the acceptable margin, between 232 and $348 \mathrm{~kg} \mathrm{ha}^{-1}$ of protected urea. But, in the right side, only one point was p between these limits. In the control chart of the moving range, the left side had two points in the right part, with four points between the SCL (Specific Control Limits). Therefore, the two sides of the individual values that were analyzed showed high applications of the nutrient in comparison to the recommended dosage of $290 \mathrm{~kg} \mathrm{ha}^{-1}$ of protected urea, and also, few points were situated between the specific limits.

The control points outside the lower and upper limits (LCL and UCL) can be explained by the special causes that occurred during the conduction of this experiment, such as, supply of the reservoir with the fertilizers - NPK; larger amount of protected urea ( $\mathrm{N}$ - nitrogen) applied in comparison to the MAP (P phosphorus) and potassium chloride ( $\mathrm{K}$ - potassium); in turn, it was shown a bigger variability in the protected urea in comparison to MAP and potassium chloride.

The fertilizer machine studied has an auger, and this thread, in turn, was not able to distribute the stipulated dosage efficiently; there was also a clogging in the cutout disks with the sugarcane straw; inadequate setting of the fertilizer machine; and still, this fertilizer has the smaller angle of repose in comparison to MAP and the potassium chloride, because the smaller this angle is, the bigger is the draining of the fertilizer in the dosing mechanism of the fertilizer machine.

Reynaldo (2013) tested several types of augers made in Brazil, being the most used in seeder-fertilizer machines. According to him, these dosing mechanisms showed inefficiency in the distribution of the fertilizers in longitudinal declivity, especially at $5^{\circ}$ and $15^{\circ}$, based on the rotation axis of this mechanism.
The augers with a thread pitch lower than 2" showed a high variation in the distribution of fertilizers, such as, PLASA 1 (12.4\%) and SEMAN 1 (26.1\%). In comparison to the dosing mechanisms with a thread pitch higher than 2", the values were lower, such as the PROT 2 (around 10.4\%) (REYNALDO, 2013).

The points that were out of the control made the process more unstable, consequently reducing the operational quality. The control chart assessed the quality of the operation through the variability of the values. Therefore, it can be said that the quality is inversely proportional to the variability.

Toledo et al. (2008), analyzing losses in the mechanized soy harvest, also found the same results in the control charts, both in individual values and moving range: points out of control, caused by special cases and affecting the process, making them unstable. According to these authors, the possible special causes were: time of production, topography of the experimental area, operational expertise of the operator among others.

\section{Individual mechanized fertilization with MAP - Monoammonium phosphate}

In the individual mechanized fertilization with MAP, the right side (R) achieved a mean of $172 \mathrm{~kg} \mathrm{ha}^{-1}$ - more than the left side (L), with $140 \mathrm{~kg} \mathrm{ha}^{-1}$ and median values close to the mean values. Regarding the standard deviation, the L side was larger (40.59) compared to the $\mathrm{R}$ side (37.53). Therefore, the $\mathrm{L}$ side values were more distributed than in the $\mathrm{R}$ side and the $\mathrm{CV}$ of the $\mathrm{L}$ side, with $29.03 \%$, was bigger than the $\mathrm{R}$ side, with $21.88 \%$, due to the variability of the data (Table 3 ).

The skewness coefficients from the sides $\mathrm{L}$ and $\mathrm{R}$ had negative skew distribution. For the kurtosis coefficient, both sides $\mathrm{L}$ and $\mathrm{R}$ presented leptokurtic distribution with more concentrated data.

Reis et al. (2015), assessing the damaged made during the mechanized sugarcane harvest, obtained positive and negative skewness coefficients with the

Table 3 - Descriptive analysis of the individual mechanized fertilization with MAP

\begin{tabular}{cccccccccc}
\hline Side & Mean* & M & $\sigma$ & CV & Amp & Cs & Ck & RJ & P \\
\hline R & $172 \mathrm{a}$ & 173.51 & 37.53 & 21.88 & 202.15 & -0.36 & 2.32 & 0.963 & $0.049 \mathrm{~A}$ \\
L & $140 \mathrm{~b}$ & 139.40 & 40.59 & 29.03 & 168.46 & -0.26 & 0.08 & 0.987 & $>0.100 \mathrm{~N}$ \\
\hline
\end{tabular}

R: right side; L: left side; M: median; $\sigma$ : standard deviation; CV: coefficient of variation; Amp: amplitude; Cs: coefficient of skewness; Ck: coefficient of kurtosis; RJ: Ryan-Joiner normality test; P: probability value through the Ryan-Joiner test; N: Normal distribution with p>0.05; A: asymmetrical distribution with $\mathrm{p}<0.05$; *Means followed by the same letter do not have statistical difference, at the $10 \%$ of significance level per the Tukey test 
skewness degree varying from low to high; regarding the coefficient of kurtosis, platykurtic and leptokurtic distributions were observed.

Skewness and kurtosis coefficients next to 0 possibly presented symmetrical distributions. However, coefficients with data further away from 0 probably showed asymmetrical distributions (REIS, 2009; REIS et al., 2015).

The Ryan-Joiner normality tests, at the $5 \%$ level on the right side, showed asymmetry; however the left side showed normality, because the values of this side presented a skewness coefficient next to 0 with normal distribution. In addition to these information, other measures are relevant to obtain normal distribution, with the average equal to 0 and constant variability of the data.

Zerbato et al. (2014, 2015) and Reis et al. (2015) also obtained similar results through the normality test with normal and asymmetrical distributions.

For the control chart of individual mechanized fertilization with MAP, it was observed a stable and controlled process in the control chart of the individual values on sides $L$ and $R$, because there was no point placed out of the control limits (Figure 4A). However, in the control charts with moving range, a point was above the upper control limit (UCL) on both sides (Figure 4B).

Points out of control cause instability in the process, which can be explained by some failure during operation and must be avoided; this result was also observed by Cassia et al. (2014), analyzing through the SQC, the damages caused by the mechanized sugarcane harvest, checking a point out of control.

For the specific limits of the individual values, on the L side ten points were situated in the acceptable margin of the specific limits. However, on the $\mathrm{R}$ side, two points were between these limits. In the control chart of the moving range, the $\mathrm{L}$ side presented two points within these limits, however, on the $\mathrm{R}$ side four points were between the SCL. This way, on both sides of the individual values, it was certified that the dosages were above the recommended, which was $100 \mathrm{~kg} \mathrm{ha}^{-1}$ of MAP - Monoammonium phosphate.

Milan and Fernandes (2002) also applied the SPC (Statistical Process Control) in operations of soil preparation, and could check a smaller variability of its data through the control of the process charts and

Figure 4 - Control chart for individual mechanized fertilization with MAP

(A)

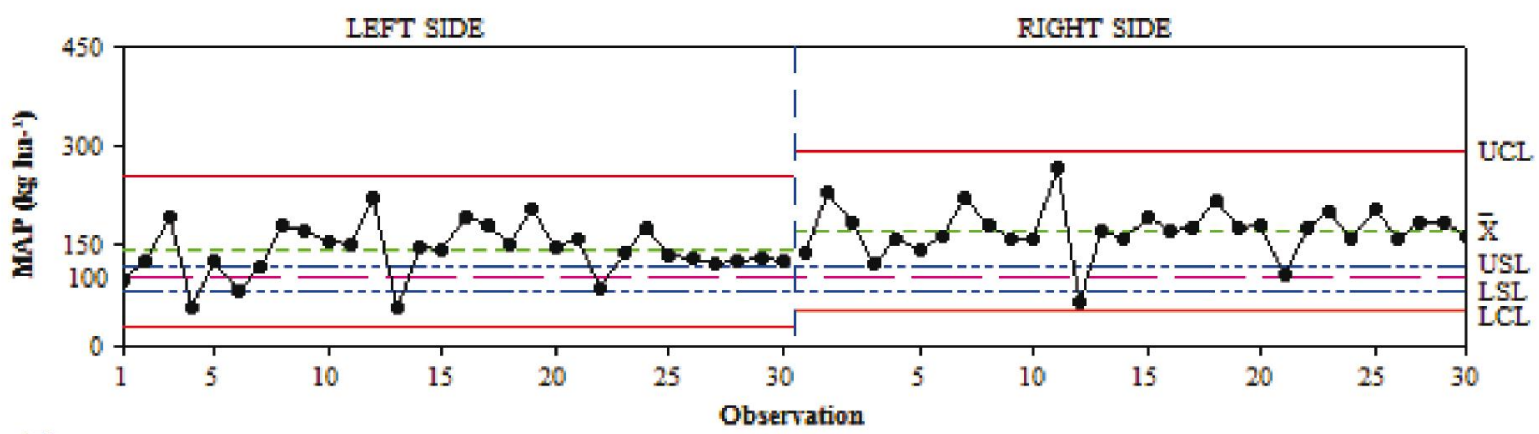

(B)

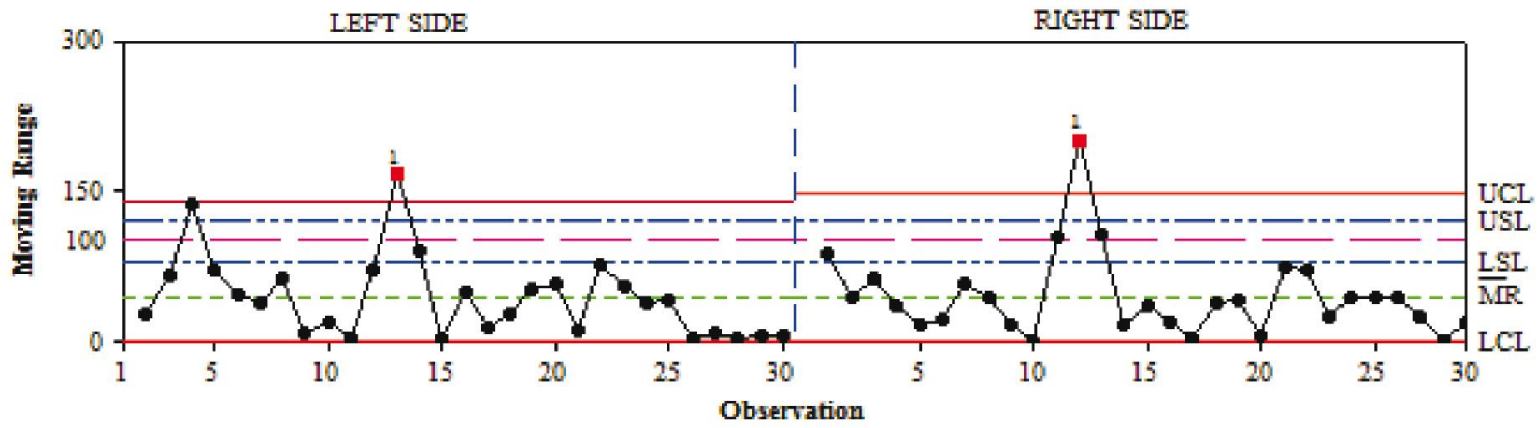

UCL: Upper Control Limit; X: Mean of the individual values; USL: Upper Specific Limit; LSL: Lower Specific Limit; LCL: Lower Control Limit; MR: Mean of the individual moving range 
histograms, since its values remained close to the Specific Control Limits (SCL), stipulated by professionals. These authors emphasized how significant and relevant the use of the SPC was in the soil preparation, facilitating the tracking of the operational quality.

Franck et al. (2015) analyzed the distribution of fertilizers through the activation speed and leaning of the dispenser, proving how the declivity of the terrain influences the rate of application of the nutrients in a different way per the analyzed dispenser. They also reported that the auger - gravity discharge showed more vulnerability regarding the transversal and longitudinal inclinations, resulting in low precision in the distribution of the fertilizers, while the helical mechanism - transverse discharge through overflow obtained a better distribution of fertilizers.

\section{Individual mechanized fertilization with potassium chloride}

For the individual mechanized fertilization with potassium chloride, the highest mean was on the right side (R), with $301 \mathrm{~kg} \mathrm{ha}^{-1}$, while on the left side (L), it was $263 \mathrm{~kg} \mathrm{ha}^{-1}$. The median values were close to the mean values. The standard deviation on the $\mathrm{R}$ side was higher (41.62) compared to the L side (33.02), and the $\mathrm{R}$ side values were further away one from the other than on the L side. Because of this, the $\mathrm{CV}$ of the $\mathrm{R}$ side was higher (13.84\%) in comparison to the $\mathrm{L}(12.55 \%)$, due to the variability of the data (Table 4).

The skewness coefficients (Cs) from the L and $\mathrm{R}$ sides had positive skew distribution. Regarding the kurtosis coefficient, the $\mathrm{R}$ side presented leptikurtic distribution, but platykurtic distribution on the L part, with more concentrated values.

According to the normality test, per RyanJoiner, at a $5 \%$ level, the $\mathrm{R}$ side presented abnormal distribution, but the L side presented normal distribution. On the L side, the values of the skewness and kurtosis coefficients remained close to 0 , presenting normal distribution. The $\mathrm{R}$ side presented higher values, causing impact with an asymmetrical distribution having more dispersed values.
Silva et al. (2013), also proved that some of the variables analyzed had normal distribution per the normality test, therefore, these presented, in the descriptive analysis, median values close to the mean values; the standard deviation with a low value; the Cs with positive and small skew distribution; and the $\mathrm{Ck}$ presented leptokurtic and platykurtic distribution. These authors also mentioned the variables with positive and high skew distribution - the mean value was away from the median value and the total amplitude expressed a high variability.

For the control chart of individual mechanized fertilization with potassium chloride, it was observed a stable and controlled process in the individual values chart on the L side, because there was no point placed out of the control limits. However, on the $\mathrm{R}$ side there was only one point out of control, situated above the UCL, due to the influence of some special cause; as a consequence, the values become instable (Figure 5A). While the moving range control charts of the $\mathrm{L}$ side kept the SPC under control, on the $\mathrm{R}$ side two points were above the UCL, causing instability in the variables, and reducing the operational quality (Figure 5B).

For the specific limits of the control charts of individual values, on both sides no point was positioned between these limits. In the moving range control chart, the $\mathrm{L}$ side had no point between the specific limits, but on the $\mathrm{R}$ side, two points remained between the specific control limits - SCL. On both sides (L/R), the dosages were above the recommended $\left(160 \mathrm{~kg} \mathrm{ha}^{-1}\right.$ of potassium chloride - $\mathrm{KCl}$ ).

Points out of the control (UCL and LCL) in process charts were found the same way by Silva et al. (2008) in the operation of mechanized sugarcane harvest, assessing its losses, where process instability was noticed, reducing the operational quality.

Reynaldo (2013) assessed different types of augers due to the inclination of the device, where it was noticed the proper distribution of the fertilizers when the machinery is positioned leveled or in a smaller declivity of the terrain, reducing the margin of error during the application of fertilizers.

Table 4 - Descriptive analysis of the individual mechanized fertilization with potassium chloride

\begin{tabular}{cccccccccc}
\hline Side & Mean* & M & $\square$ & CV & Amp & Cs & Ck & RJ & P \\
\hline R & $301 \mathrm{a}$ & 291.85 & 41.62 & 13.84 & 208.04 & 2.43 & 7.79 & 0.870 & $<0.010 \mathrm{~A}$ \\
$\mathrm{~L}$ & $263 \mathrm{~b}$ & 265.32 & 33.02 & 12.55 & 120.45 & 0.41 & -0.61 & 0.982 & $>0.100 \mathrm{~N}$ \\
\hline
\end{tabular}

R: right side; L: Left side; M: median; $\square$ : standard deviation; CV: coefficient of variation; Amp: amplitude; Cs: coefficient of skewness; Ck: coefficient of kurtosis; RJ: Ryan-Joiner normality test; P: probability value through the Ryan-Joiner test; A: asymmetrical distribution; N: normal distribution with $\mathrm{p}>0.05$; *Means followed by the same letter do not have statistical difference, at the $10 \%$ of significance level per the Tukey test 
Figure 5 - Control chart for individual mechanized fertilization with potassium chloride

(A)

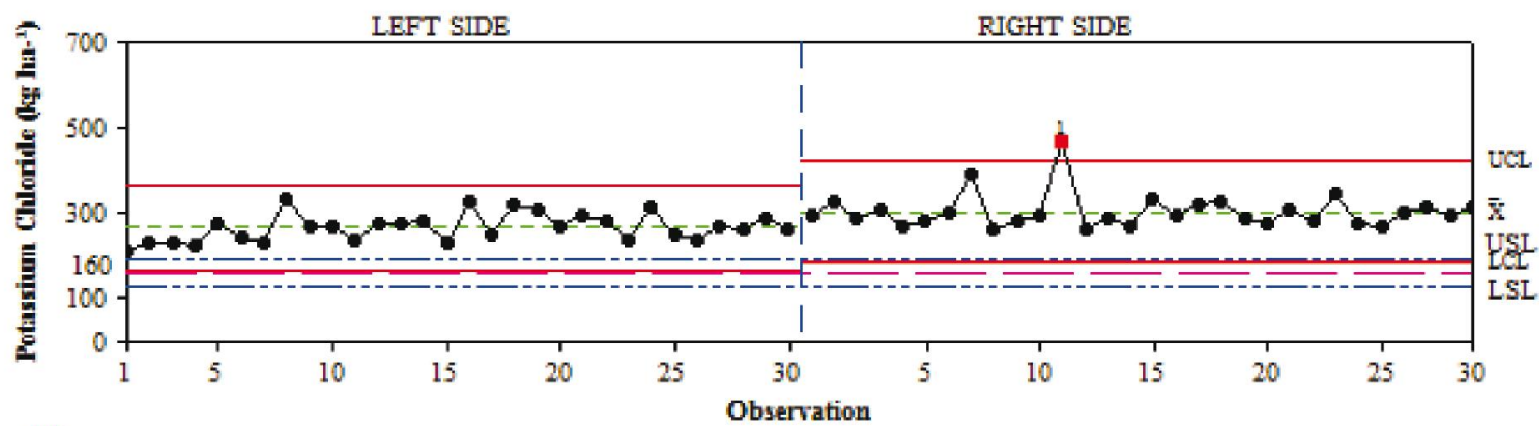

(B)

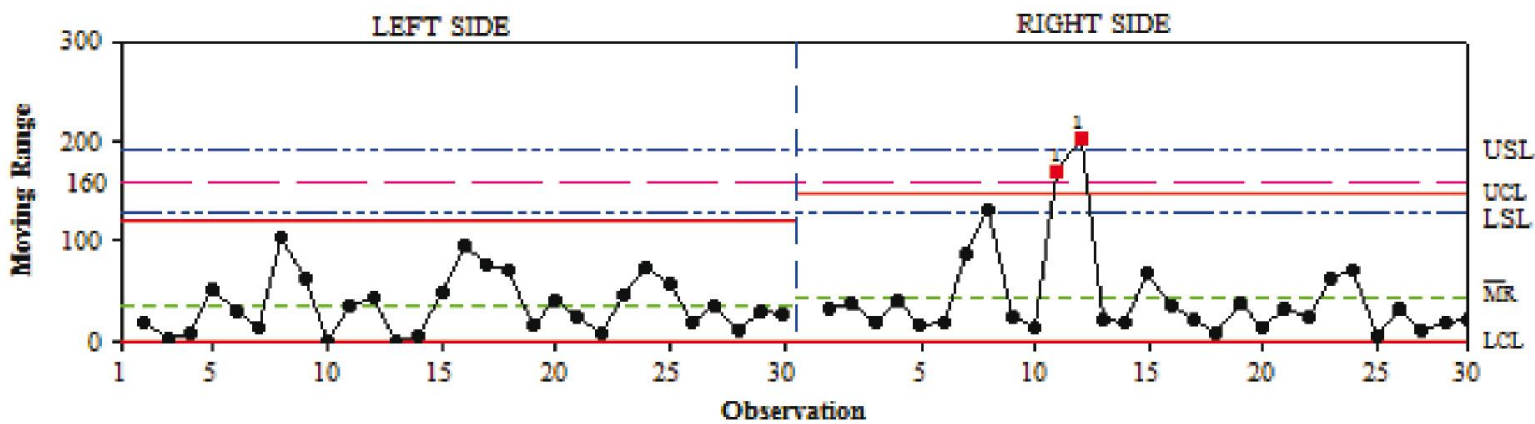

UCL: Upper Control Limit; X: Mean of the individual values; USL: Upper Specific Limit; LSL: Lower Specific Limit; LCL: Lower Control Limit; MR: Mean of the individual moving range

\section{CONCLUSIONS}

1. The mechanized fertilization with individualized distribution system of protected urea, MAP and potassium chloride (N-P-K) presented, through the control charts, greater distribution regarding the dosage recommended for each fertilizer, due to the helical mechanism of distribution of the fertilizer machine and inadequate setting;

2. The largest dosage applied was of protected urea, presenting higher variability between the nutrients as a consequence of the smaller angle of repose, since the smaller is the angle, the bigger is the draining of the nutrient;

3. The MAP was applied in smaller amounts, showing less variability and better distribution of the values.

\section{REFERENCES}

CASSIA, M. T. et al. Desgaste das facas do corte basal na qualidade da colheita mecanizada de cana-de-açúcar. Ciência Rural, v. 44, n. 6, p. 987-993, 2014.

COMPANHIA NACIONAL DE ABASTECIMENTO. Acompanhamento da safra brasileira: cana-de-açúcar. Brasília,
2015. Disponível em:<http://www.conab.gov.br/OlalaCMS/ uploads/arquivos/15_04_13_08_45_51_boletim_cana_ portugues_-_4o_lev_-_14-15.pdf >. Acesso em: 19 abr. 2015.

FRANCK, C. J. et al. Modelos estatísticos para seleção de dosadores helicoidais com diferentes dispositivos de descarga de fertilizante. Revista Brasileira de Engenharia Agrícola e Ambiental, v. 19, n. 5, p. 512-518, 2015.

MILAN, M.; FERNANDES, R. T. Qualidade das operações de preparo de solo por controle estatístico de processo. Scientia Agrícola, v. 59, n. 2, p. 261-266, 2002.

MINITAB. MINITAB release 16: meet MINITAB 16: MINITAB statguide, MINITAB help. Philadelphia, 2007.

MONTGOMERY, D. C. Introdução ao controle estatístico da qualidade. 4. ed. Rio de Janeiro: LTC, 2009. p. 100-200.

MOTOMIYA, A. V. de A. et al. Variabilidade espacial de atributos químicos do solo e produtividade do algodoeiro. Revista Agrarian, v. 4, n. 11, p. 1-9, 2011.

NORONHA, R. H. de F. et al. Controle estatístico aplicado ao processo de colheita mecanizada diurna e noturna de cana-deaçúcar. Bragantia, v. 70, n. 4, p. 931-938, 2011.

REIS, G. N. dos. et al. Qualidade do corte basal na colheita mecanizada de cana-de-açúcar em dois tipos de manejo do solo. Comunicata Scientiae, v. 6, n. 2, p. 143-153, 2015.

REIS, G. N. dos. Perdas na colheita mecanizada da canade-açúcar crua em função do desgaste das facas do corte 
de base. 2009. 89 f. Tese (Doutorado em Agronomia - Ciência do Solo) - Universidade Estadual Paulista "Júlio de Mesquita Filho", Faculdade de Ciências Agrárias e Veterinárias, Câmpus de Jaboticabal, Jaboticabal, 2009.

REYNALDO, É. F. Avaliação de mecanismos dosadores de fertilizantes sólidos tipo helicoidais em diferentes níveis de nivelamento longitudinal e transversal. 2013. $94 \mathrm{f}$. Tese (Doutorado em Agronomia - Energia na Agricultura) - Universidade Estadual Paulista "Júlio de Mesquita Filho", Faculdade de Ciências Agronômicas, Câmpus de Botucatu, Botucatu, 2013.

SILVA, R. P da. et al. Controle estatístico aplicado ao processo de colheita mecanizada de cana-de-açúcar. Engenharia Agrícola, v. 28 , n. 2, p. 292-304, 2008.

SILVA, R. P. da et al. Qualidade da colheita mecanizada de feijão (Phaseolus vulgaris) em dois sistemas de preparo do solo. Revista Ciência Agronômica, v. 44, n. 1, p. 61-69, 2013.

TAVARES, T. de O. et al. Qualidade do recolhimento mecanizado do café. Coffee Science, v. 10, n. 4, p. 455-463, 2015.
TOLEDO, A. de et al. Caracterização das perdas e distribuição de cobertura vegetal em colheita mecanizada de soja. Engenharia Agrícola, v. 28, n. 4, p. 710-719, 2008.

VITTI, G. C. et al. Nutrição e adubação da cana-de-açúcar. Bebedouro, 2005. Disponível em: <http://www.agencia. cnptia.embrapa.br/Repositorio/Nutricao+cana+GVitti_ 000fh3r3vzp02wyiv80rn0etnmc6zamd.pdf>. Acesso em: 21 jun. 2014.

VOLTOLINI, T. V. et al. Valor nutritivo de cultivares de cana-deaçúcar sob irrigação. Revista Brasileira de Saúde e Produção Animal, v. 13, n. 4, p. 894-901, 2012.

ZERBATO, C. et al. Desempenho operacional do conjunto trator-semeadora-adubadora de amendoim em função de densidades de semeadura e tamanho das sementes. Energia na Agricultura, v. 30, n. 2, p. 143-149, 2015.

ZERBATO, C. et al. Peanut mechanized digging regarding to plant population and soil water level. Revista Brasileira de Engenharia Agrícola e Ambiental, v. 18, n. 4, p. 459-465, 2014. 